\title{
Mass spectral characterization of primary emissions and implications in source apportionment of organic aerosol
}

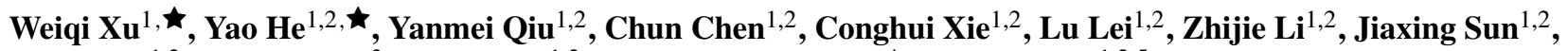 \\ Junyao Li ${ }^{1,2}$, Pingqing Fu ${ }^{3}$, Zifa Wang ${ }^{1,2}$, Douglas R. Worsnop ${ }^{4}$, and Yele Sun ${ }^{1,2,5}$ \\ ${ }^{1}$ State Key Laboratory of Atmospheric Boundary Layer Physics and Atmospheric Chemistry, Institute of Atmospheric \\ Physics, Chinese Academy of Sciences, Beijing 100029, China \\ ${ }^{2}$ College of Earth and Planetary Sciences, University of Chinese Academy of Sciences, Beijing 100049, China \\ ${ }^{3}$ Institute of Surface-Earth System Science, Tianjin University, Tianjin 300072, China \\ ${ }^{4}$ Aerodyne Research Inc., Billerica, Massachusetts 01821, USA \\ ${ }^{5}$ Collaborative Innovation Center on Forecast and Evaluation of Meteorological Disasters, Nanjing University of Information \\ Science and Technology, Nanjing 210044, China \\ ฟThese authors contributed equally to this work.
}

Correspondence: Yele Sun (sunyele@mail.iap.ac.cn)

Received: 25 February 2020 - Discussion started: 9 March 2020

Revised: 14 May 2020 - Accepted: 20 May 2020 - Published: 18 June 2020

\begin{abstract}
Source apportionment of organic aerosol (OA) from aerosol mass spectrometer (AMS) or aerosol chemical speciation monitor (ACSM) measurements relies largely upon mass spectral profiles from different source emissions. However, the changes in mass spectra of primary emissions from AMS-ACSM with the newly developed capture vaporizer $(\mathrm{CV})$ are poorly understood. Here we conducted 21 cooking, crop straw, wood, and coal burning experiments to characterize the mass spectral features of OA and watersoluble OA (WSOA) using SV-AMS and CV-ACSM. Our results show overall similar spectral characteristics between SV-AMS and CV-ACSM for different primary emissions despite additional thermal decomposition in $\mathrm{CV}$, and the previous spectral features for diagnostics of primary OA factors are generally well retained. However, the mass spectral differences between OA and WSOA can be substantial for both SV-AMS and CV-ACSM. The changes in $f_{55}$ (fraction of $m / z 55$ in OA) vs. $f_{57}, f_{44}$ vs. $f_{60}$, and $f_{44}$ vs. $f_{43}$ in CVACSM are also observed, yet the evolving trends are similar to those of SV-AMS. By applying the source spectral profiles to a winter CV-ACSM study at a highly polluted rural site in the North China Plain, the source apportionment of primary OA was much improved, highlighting the two most important primary sources of biomass burning and coal combustion ( $32 \%$ and $21 \%$ ). Considering the rapidly increasing deploy-
\end{abstract}

ments of CV-ACSM and WSOA studies worldwide, the mass spectral characterization has significant implications by providing essential constraints for more accurate source apportionment and making better strategies for air pollution control in regions with diverse primary emissions.

\section{Introduction}

Organic aerosol (OA) is ubiquitous in the atmosphere and often contributes a large fraction of aerosol particles. Currently, the Aerodyne aerosol mass spectrometer (AMS) is one of the most widely used instruments for real-time measurements of OA (Canagaratna et al., 2007; Li et al., 2017). OA can be further separated into primary OA (POA) and secondary OA (SOA) factors by using receptor models, e.g., positive matrix factorization (PMF) and a multilinear engine (ME2) (Paatero, 1999; Paatero and Tapper, 1994). The determination of $\mathrm{OA}$ factors relies strongly upon the comparisons with collocated measurements and also the mass spectral profiles of primary emissions. However, in the absence of collocated measurements, the spectral features become the most important constraint for selection of PMF factors. As a result, the mass spectra of primary emissions have been extensively characterized with a quadrupole and high-resolution 
time-of-flight (ToF) AMS, including traffic exhaust (Canagaratna et al., 2004; Collier et al., 2015), biomass burning (Schneider et al., 2006; Alfarra et al., 2007), and cooking emissions (Mohr et al., 2009; He et al., 2010; Allan et al., 2010; Robinson et al., 2018), and the spectral characteristics, e.g., hydrocarbon ion series $\mathrm{C}_{n} \mathrm{H}_{2 n-1}^{+}$and $\mathrm{C}_{n} \mathrm{H}_{2 n+1}^{+}$for traffic emissions, $f_{60}$ (fraction of $m / z 60$ in OA) for biomass burning, and high $f_{55} / f_{57}$ for cooking OA, are widely used as diagnostics for the presence of OA factors. However, coal combustion emissions, one of the most important primary sources in north China in winter, are rarely characterized (Lin et al., 2017). Owing to the relatively similar spectra between coal combustion OA (CCOA) and traffic-related hydrocarbon-like $\mathrm{OA}(\mathrm{HOA})$, and the decreases in coal combustion emissions in Beijing in recent years, it becomes more challenging to separate these two fossil-fuel-related factors (Sun et al., 2016a; Xu et al., 2019), particularly for unit mass resolution spectra measured by an aerosol chemical speciation monitor (ACSM). Therefore, it is of great importance to characterize the spectral features of CCOA for a better quantification of coal combustion emissions.

Although AMS-ACSM are capable of measuring OA in real time, the uncertainties in quantification can be up to $38 \%$ (Bahreini et al., 2009) mainly due to the influence of collection efficiency (CE) caused by particle bouncing from the vaporizer (Huffman et al., 2005; Matthew et al., 2008). While the parameterization of $\mathrm{CE}$ as a function of particle phase, acidity, and the fraction of ammonium nitrate (Middlebrook et al., 2012) has improved the AMS-ACSM quantification, the applications for the $\mathrm{PM}_{2.5}$ lens and particles larger than $1 \mu \mathrm{m}$ remain unknown. As a result, a new capture vaporizer (CV) with an enclosed cavity was developed (Xu et al., 2017b). Field measurements showed that the CE of CV-AMS was fairly robust at $\sim 1$ (Hu et al., 2017). However, the OA mass spectra can have significant changes in CV by shifting towards smaller fragments compared to a standard vaporizer (SV) due to additional thermal decomposition (Hu et al., 2018a, b). To our knowledge, the mass spectral differences between CV and SV and the mass spectral features of primary emissions in CV-AMS-ACSM are not yet well understood. Hence, it is critically important to re-characterize the mass spectra of primary emissions in $\mathrm{CV}$ and to provide essential constraints for OA source apportionment from the rapidly increasing CV-ACSM measurements worldwide.

In recent years, water-soluble OA (WSOA), which plays an important role in affecting aerosol hygroscopicity and cloud condensation nuclei formation, has attracted increasing attention (Bozzetti et al., 2017; Xu et al., 2017a; Qiu et al., 2019; Ye et al., 2017). Due to the challenges in realtime online measurements of WSOA, most previous studies focus on offline analysis of WSOA using SV-AMS. The results showed that oxygenated OA (OOA) and biomass burning $\mathrm{OA}(\mathrm{BBOA})$ are generally more water-soluble than other primary source emissions, e.g., traffic and cooking (MayolBracero et al., 2002; Daellenbach et al., 2016). Because of the different water solubility of OA factors, the mass spectra of WSOA can be substantially different from the total OA, which increases the difficulties in separation of the WSOA factors in source apportionment of WSOA. Although several studies tried to use a ME-2 for a better source apportionment of less water-soluble components, e.g., HOA and cooking OA (COA), by using the ambient resolved spectra as constraints (Bozzetti et al., 2017; Daellenbach et al., 2016), it could introduce additional uncertainties when water-soluble HOA and COA were different from the constrained spectra. Unfortunately, mass spectral characterization of WSOA from different primary emissions using SV-AMS and CV-ACSM is extremely limited. Thus, there is an urgent need for characterization of the mass spectra of WSOA from different primary emissions, which has a great potential to improve the future source apportionment of WSOA.

In this work, we conducted 21 cooking and burning experiments to characterize the mass spectral features of OA and water-soluble OA from cooking emissions, crop straw burning, wood burning, and coal combustion using SVAMS and CV-ACSM. The mass spectra of OA and WSOA from CV-ACSM are compared with those of SV-AMS, and the changes in specific marker $m / z$ 's for different primary sources are elucidated. In particular, we demonstrate the importance of applying mass spectra of primary emissions to receptor models for a better source apportionment of OA in a highly polluted environment with complex primary emissions.

\section{Experimental methods}

\subsection{Experimental setup}

A total of 21 experiments were conducted including seven cooking with different oils (stir-fried garlic with corn oil, stir-fried celery with corn oil, peanut oil, bean oil, sunflower oil, blend oil, and lard oil), one barbecue, five crop straw burning (dry wheat, corn, bean, rape, and cotton) and four wood burning (dry birchen, pine tree, poplar, and Chinese oak) under smoldering-dominated conditions and four coal combustion (brown and bituminous coal) under both flaming and smoldering conditions in June 2019. The average $( \pm 1 \sigma)$ temperature and relative humidity during the experiments were $24.6( \pm 3.4){ }^{\circ} \mathrm{C}$ and $59.5( \pm 23.1) \%$. All fuels were burned in a common residential stove outside a $50 \mathrm{~m}^{3}$ tent, and aerosol particles were then emitted into the tent through a chimney (Fig. 1). After approximately $5 \mathrm{~min}$, a high-volume sampler (TISCH) was first used to collect $\mathrm{PM}_{2.5}$ samples for $10 \mathrm{~min}$, and then a HR-AMS equipped with an SV and $\mathrm{PM}_{1}$ lens (SV-AMS hereafter) and a ToFACSM equipped with a CV and $\mathrm{PM}_{2.5}$ lens (CV-ACSM hereafter) were operated in parallel to measure organic aerosol particles for approximately $15 \mathrm{~min}$. Because the real-time measurements of $\mathrm{CO}_{2}$ were not available, a HEPA filter was 
placed in front of the sampling line before and after the SVAMS and CV-ACSM measurements to correct the influence of gaseous $\mathrm{CO}_{2}$ on the total $m / z$ 44. After the burning experiment, the room was ventilated completely until the mass concentrations of aerosol particles were close to the ambient values that were measured by the other CV-ACSM nearby.

Cooking experiments were conducted inside the tent by simulating the real Chinese cooking styles with different oils. To avoid the influences from burning of the fuel, an induction cooker was used in this study. In comparison, the barbecue experiment was performed using mutton shashlik and anthracite as ingredient and fuel, respectively, which are the most popular barbecue styles in restaurants. Burning anthracite alone was found to emit significantly lower mass loadings of aerosol particles than those emitted from the barbecue.

The average mass loadings of OA during the burning and cooking experiments are nearly 2 orders of magnitude higher than in ambient air, indicating the negligible influences of background OA on our experiments. As shown in Table S1 in the Supplement, the mass concentrations of OA measured by SV-AMS ranged from $\sim 80$ to $\sim 1370 \mu \mathrm{g} \mathrm{m}^{-3}$ for different burning experiments by using a relative ionization efficiency of 1.4 and a collection efficiency of 1 . Considering that the mass spectra of OA can have changes across different mass loadings due to the partitioning of semi-volatile organic compounds (Donahue et al., 2006; Shilling et al., 2009), we further checked the spectral differences between high and low mass loadings for SV-AMS and CV-ACSM (Tables S1 and S2, respectively). As indicated in Figs. S1 and S2 in the Supplement, the mass spectra of OA and $f_{44}$, $f_{43}$, and $f_{60}$ from cooking and flaming combustion of coal are remarkably similar under low and high mass loadings, indicating that the mass spectra are relatively stable upon dilution or evaporation and thus can be used well as constraints in source apportionment analysis. Although the mass spectra of OA for the other burning, i.e., biomass burning, wood burning, and smoldering combustion of coal, are also highly similar between low and high mass loadings, the ubiquitous increases in $f_{44}$ and corresponding decreases in $f_{60}$ were observed from high to low mass loadings. For instance, $f_{44}$ in SV-AMS was increased by $0.4 \%-2 \%$ as the mass loading decreased by a factor of $\sim 3$, and $f_{60}$ showed a corresponding decrease by $0.1 \%-0.9 \%$. Similarly, $f_{44}$ in CV-ACSM was increased by $0.9 \%-4.2 \%$ associated with a decrease in $f_{60}$ by $0.1 \%-0.6 \%$ as OA mass loadings were decreased by a factor of $\sim 3-4$. Such results are consistent with previous studies that biomass burning OA can be rapidly aged in the atmosphere, which is characterized by increases in $f_{44}$ and decreases in $f_{60}$ (Cubison et al., 2011; Morgan et al., 2020). Therefore, source apportionment of OA using the source spectra from biomass burning, wood burning, and smoldering combustion of coal needs to consider the mass loading effects and increase the variability uncertainties in $f_{44}$ and $f_{60}$.

\subsection{Chemical and data analysis}

PIKA 1.57 and Tofware v2.5.13 were used for determination of mass concentrations and mass spectra of OA measured by SV-AMS and CV-ACSM, respectively. The elemental ratios of OA measured by SV-AMS including hydrogen-tocarbon $(\mathrm{H} / \mathrm{C})$, oxygen-to-carbon $(\mathrm{O} / \mathrm{C})$, nitrogen-to-carbon $(\mathrm{N} / \mathrm{C})$, and organic mass-to-organic carbon $(\mathrm{OM} / \mathrm{OC})$ ratios in this study were calculated using the improved-ambient (IA) method (Canagaratna et al., 2015). The offline analysis of WSOA with SV-AMS and CV-ACSM is similar to that reported in our previous study (Qiu et al., 2019). Briefly, two or three punches of filter samples were sonicated in $25 \mathrm{~mL}$ of deionized water and then filtered with $0.45 \mu \mathrm{m}$ syringe filters (Anpel, PVDF). An aliquot of the solution was atomized using pure argon, dried by the Nafion dryer, and then simultaneously measured by SV-AMS and CV-ACSM. Different from WSOA in ambient aerosol (Qiu et al., 2019), the ratio of $\mathrm{CO}^{+} / \mathrm{CO}_{2}^{+}$varied largely among different burning experiments, for example, 0.78-1.40 for cooking, 2.07-2.53 for crop straw burning, 1.50-2.45 for wood burning, and 1.501.85 for coal combustion (Fig. 2). For a better comparison with OA measured by SV-AMS, $\mathrm{CO}^{+}$was scaled to be equal to $\mathrm{CO}_{2}^{+}$for all WSOA samples. We found that the $\mathrm{O} / \mathrm{C}$ ratios calculated with $\mathrm{CO}^{+}=\mathrm{CO}_{2}^{+}$and the fitted values have differences by $0.6 \%-11.6 \%$. In addition, organic carbon (OC), elemental carbon (EC), and water-soluble OC (WSOC) in $\mathrm{PM}_{2.5}$ samples were analyzed by a Sunset OC-EC analyzer (Sunset Laboratory Inc., model-4) and a total organic carbon (TOC) analyzer (Shimadzu, TOC-L). A more detailed description of carbonaceous aerosol analysis is given elsewhere (Li et al., 2018).

\section{Results and discussion}

\subsection{Cooking emissions}

The mass spectral profiles of eight cooking OAs are shown in Figs. 3, 4, and S3. All COA spectral profiles measured by SV-AMS and CV-ACSM are highly similar $\left(R^{2}>0.89\right.$, Fig. 5) and also resemble those previously resolved in ambient air during all seasons in Beijing (Fig. S4) despite the fact that COA concentrations can have a difference of an order of magnitude. We also noticed slightly higher $\mathrm{O} / \mathrm{C}\left(f_{44}\right)$ for COA under lower mass loadings, which were likely due to partitioning of more semi-volatile organics on particles during periods with higher mass loadings (Reyes-Villegas et al., 2018a). These results suggest fairly robust COA spectra for different cooking oils. One explanation is the relatively similar ingredients of cooking oils that are generally dominated by fatty acids and carbonyls (Schauer et al., 2002). Consistent with previous studies (Sun et al., 2011; Mohr et al., 2012), the source spectra of COA from SV-AMS are characterized by high $f_{55} / f_{57}$ (fraction of $m / z 55$ and 57 in OA, re- 


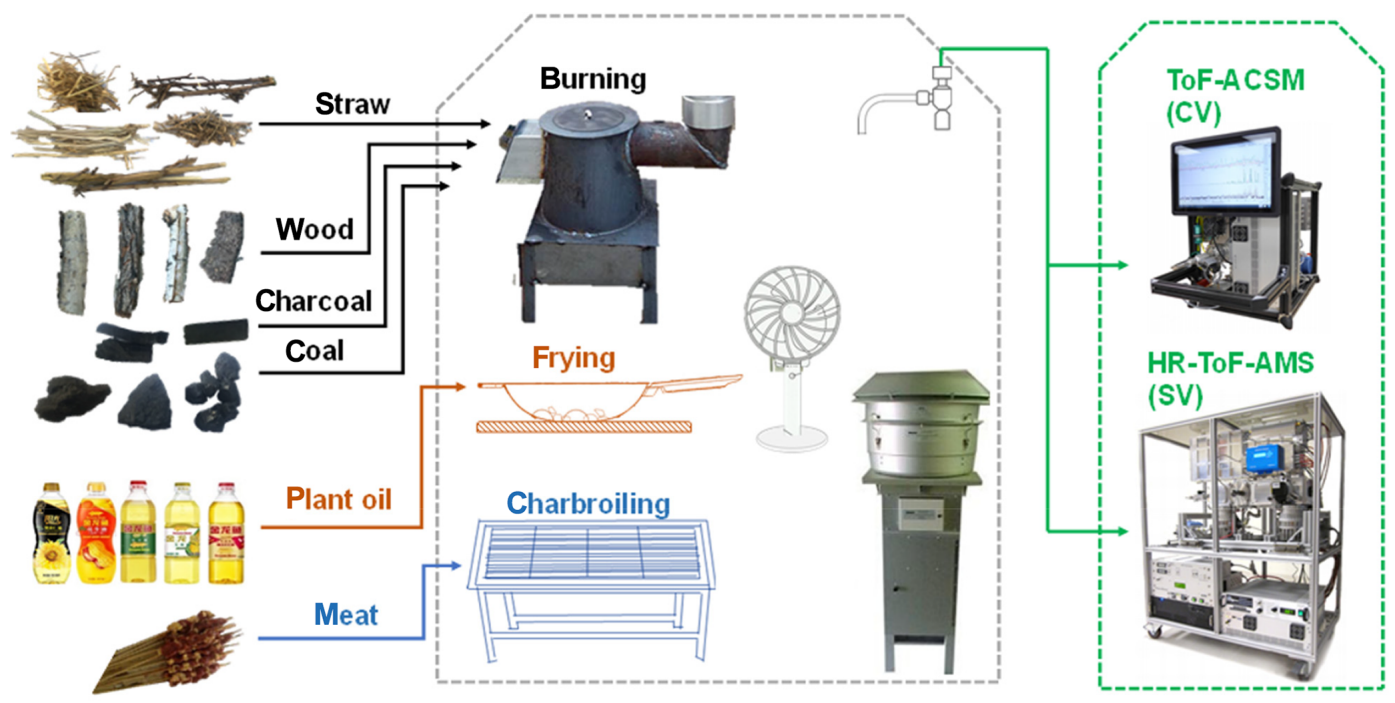

Figure 1. Schematic of cooking and burning experiments.

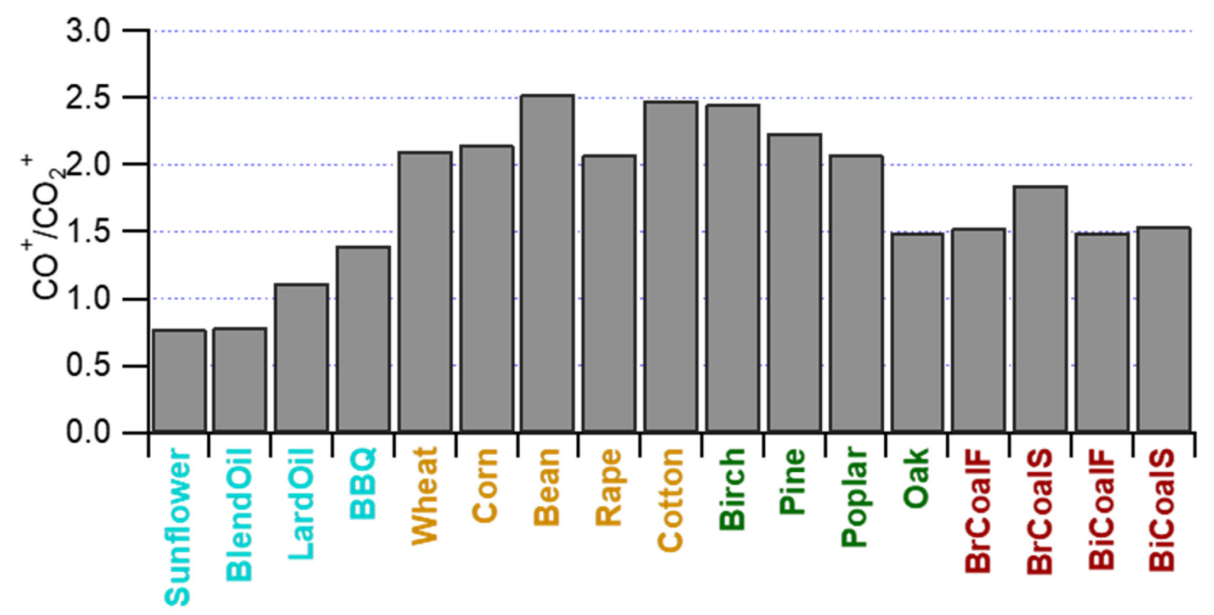

Figure 2. The ratio of measured $\mathrm{CO}^{+} / \mathrm{CO}_{2}^{+}$for WSOA from 17 cooking and burning experiments.

spectively) ratios $(2.0-2.7)$ and low $\mathrm{O} / \mathrm{C}$ ratios $(0.15-0.18)$. These results indicate that the COA source spectra can be used as good constraints for a better source apportionment of COA. We also observed considerable N-containing ions in COA spectra, and the average $\mathrm{N} / \mathrm{C}$ ratios ranged from 0.005 to 0.033 . Such high $\mathrm{N} / \mathrm{C}$ ratios suggest that cooking emissions can be a significant source of organic nitrogen (ON) in ambient air, in agreement with our previous study showing two ON peaks during mealtimes (Xu et al., 2017d), and also the ubiquitous identification of nitrogen-containing compounds from cooking emissions (Reyes-Villegas et al., 2018a). Note that the $\mathrm{N} / \mathrm{C}$ ratio of ambient COA identified by PMF in Beijing (0.002-0.015) (Sun et al., 2016a; $\mathrm{Xu}$ et al., 2017c, 2019) is generally lower than that from cooking emissions (Fig. S5). One reason is due to the challenges in separation and quantification of $\mathrm{N}$-containing ions in ambient OA, particularly for the low-mass-resolution $\mathrm{V}$ mode measurements. We also noticed pronounced $\mathrm{m} / \mathrm{z} 60$ $\left(f_{60}=0.57 \%-0.96 \%\right)$ and $m / z 73\left(f_{73}=0.59 \%-1.1 \%\right)$ in COA source spectra, which are generally used as biomass burning tracers (Cubison et al., 2011). Because an induction cooker was used in this study, the signals of $f_{60}$ and $f_{73}$ would be completely from cooking oils. Previous studies also observed such signals from laboratory-generated cooking emissions, for example, palm oil COA (Liu et al., 2017, 2018), fresh COA (Kaltsonoudis et al., 2017), heating of frying oil, and deep-frying (Faber et al., 2013). Although the chemical ionization mass spectrometer was able to detect high concentrations of levoglucosan in cooking emissions (Reyes-Villegas et al., 2018a), the ratios of $f_{60} / f_{73}$ in COA from SV-AMS are fairly constant ( 1, Fig. 6), which are approximately 2 times lower than those observed in biomass 
burning OA $(\sim 2$, Fig. 6$)$. These results highlight the contributions of other cooking-related oxygenated compounds to $m / z 60$ and $m / z 73$.

As shown in Figs. 3 and S6, all COA spectra of CV-ACSM are fairly stable and overall similar to those of SV-AMS $\left(R^{2}>0.86\right)$. Due to additional thermal decomposition in $\mathrm{CV}$, the COA source spectra in CV showed slightly higher $f_{44}$ $(2.4 \%-3.7 \%)$ than that of SV-AMS $(1.8 \%-2.9 \%)$ (Hu et al., 2018a). The major COA spectral differences between CVACSM and SV-AMS are the changes in $\mathrm{C}_{n} \mathrm{H}_{2 n-1}^{+} / \mathrm{C}_{n} \mathrm{H}_{2 n+1}^{+}$ ratios, e.g., $m / z 41 / 43, m / z 55 / 57$, and $m / z 67 / 69$. For example, the $m / z 55 / 57$ ratios ranged from 2.8 to 5.4 in CVACSM, which were consistent with those of cooking exhaust near a kitchen ventilator (4.05) measured by another similar CV-ACSM (Zheng et al., 2020), yet the ratios were approximately 2 times higher than those in SV-AMS (2.0-2.7, Fig. 6). Similarly, the ratios of $m / z 41 / 43$ and $m / z 67 / 69$ in CV-ACSM (1.2-1.9 and 1.2-2.6, respectively) are also much higher than those in SV-AMS. In addition, we found that the prominent $\mathrm{m} / \mathrm{z}, 60$ and 73 signals in CV-ACSM were much smaller than those in SV-AMS, likely due to additional thermal decomposition in CV.

The mass spectra of water-soluble COA (WSCOA) are much different from those of total COA for both SV-AMS and CV-ACSM in terms of elemental composition and $f_{44}$. As indicated in Figs. 4 and S3, the O/C ratios of WSCOA range from 0.33 to 0.45 , which are much higher than $0.15-0.18$ of COA, suggesting that WSCOA contains more oxygenated organic compounds. This is consistent with the much higher $\mathrm{C}_{x} \mathrm{H}_{y} \mathrm{O}^{+}$and $\mathrm{C}_{x} \mathrm{H}_{y} \mathrm{O}_{z}^{+}$families $(23.4 \%-$ $34.5 \%$ and $10.0 \%-12.5 \%$, respectively) in WSCOA than COA $(14.8 \%-18.0 \%$ and $6.9 \%-7.9 \%$, respectively). Similarly, the $f_{44}$ of WSCOA is higher than that in COA by more than a factor of 2. We also noticed much higher $\mathrm{N} / \mathrm{C}$ ratios in WSCOA than COA, indicating enriched nitrogen-containing organic compounds in water-soluble COA. Despite the differences above, the mass spectral features of COA, i.e., high $\mathrm{m} / \mathrm{z} 55$ and 57, and $\mathrm{m} / \mathrm{z} 55 / 57$ ratio are well retained in WSCOA from animal oil for both SV-AMS and CV-ACSM (Fig. 4), while there are more changes in WSCOA from vegetable oil with much reduced $f_{55}$ and $f_{57}$. One reason is due to the different water solubility of COA between vegetable and animal oils. Our carbon analysis showed that COA from vegetable oil has higher water solubility compared to that from animal oil as indicated by the higher WSOC/OC ratios $(\sim 30$ vs. $17 \%)$. As a result, the $\mathrm{O} / \mathrm{C}$ ratio and $f_{44}$ in WSOA from vegetable oil are correspondingly higher than those from animal oil. By comparing with the source spectra of WSCOA, we found that the previously resolved ambient WSCOA in urban Beijing $(\mathrm{O} / \mathrm{C}=0.38$ and WSCOA $/ \mathrm{OA}=$ $19 \%$ ) (Qiu et al., 2019) tends to be a mixture from cooking both vegetable and animal oils.

\subsection{Crop straw burning}

The mass spectral profiles of biomass burning have been relatively well characterized by SV-AMS in previous studies (Weimer et al., 2008; Lee et al., 2010; Schneider et al., 2006; Alfarra et al., 2007), and $m / z 60$ (mainly $\mathrm{C}_{2} \mathrm{H}_{4} \mathrm{O}_{2}^{+}$) and 73 (mainly $\mathrm{C}_{3} \mathrm{H}_{5} \mathrm{O}_{2}^{+}$) from fragmentation of anhydrosugars (e.g., levoglucosan) are widely used as biomass burning markers in ambient studies. We found that $f_{60}$ measured by SV-AMS varied largely among different crop straw fuels ranging from 0.8 to $2.6 \%$ (Figs. 3 and S3), which is generally close to the values reported in previous studies (Sun et al., 2016b; Gilardoni et al., 2016) but much higher than that from open straw burning $\left(f_{60}=0.3 \%-0.6 \%\right)$ (Fang et al., 2017). One explanation is that $f_{60}$ depends on biomass fuels, burning conditions (e.g., flaming or smoldering), and also chemical aging (Hennigan et al., 2011; Schneider et al., 2006; Collier et al., 2016). In addition, we also observed relatively high fractions of $\mathrm{C}_{x} \mathrm{H}_{y} \mathrm{~N}_{z}^{+}$in BBOA $(4.2 \%-10.2 \%)$ and high $\mathrm{N} / \mathrm{C}$ ratios $(0.014-0.039)$, consistent with the observations of abundant nitrogen-containing organic compounds, e.g., N-heterocyclic alkaloid compounds, amines, and nitrated phenols from biomass burning (Reyes-Villegas et al., 2018b; Bottenus et al., 2018; Wang et al., 2017; Laskin et al., 2009; Desyaterik et al., 2013). Compared with SV-AMS, the BBOA spectra of CV-ACSM are overall similar $\left(R^{2}=0.93\right.$ 0.96, Fig. S6) except the burning of wheat and corn stalk $\left(R^{2}=0.80\right)$. As expected, $f_{60}$ in CV-ACSM is lower than that in SV-AMS (1.0 vs. $1.7 \%$ ), while $f_{44}$ is correspondingly higher (5.9 vs. $2.7 \%$ ) due to strong thermal decomposition in CV. Although the $f_{60}$ signal is low, it can still be used as a biomass burning marker for CV-AMS-ACSM (Hu et al., 2018a). It should be noted that the $f_{44}$ of crop straw burning measured by $\mathrm{CV}$ in this study is lower than that identified in ambient aerosol by the ToF-ACSM in Gucheng, likely indicating that ambient BBOA has been photochemically aged to some extent.

The mass spectra of water-soluble BBOA (WSBBOA) resemble those of BBOA for both SV-AMS and CV-ACSM (Figs. 4 and S3). One reason is due to the high solubility of BBOA of which $\sim 40 \%-70 \%$ of carbon was found to be water-soluble. This is consistent with the observation from a combustion chamber experiment (65\%) (Zheng et al., 2020). It should be noted that the $f_{60}$ of WSBBOA measured by CV-ACSM in this study is higher than that reported in Zheng et al. (2020), likely due to the differences in combustion system and ACSM detectors. WSBBOA presents generally higher $f_{60}$ and $f_{44}$ than the total BBOA for SV-AMS (2.4 vs. $1.7 \%$ and 4.1 vs. $2.7 \%$, respectively) and CV-ACSM (1.6 vs. $1.0 \%$ and 8.7 vs. $5.9 \%$, respectively). As shown in Fig. S7, the slope of $f_{44}$ is less than 1 for both SV-AMS and CV-ACSM, and all data points are located in the right bottom corner, in agreement with the higher $\mathrm{O} / \mathrm{C}$ ratios of WSOA than OA. In fact, the $\mathrm{O} / \mathrm{C}$ ratios of WSBBOA are approximately $50 \%$ higher than those of BBOA, although they are 

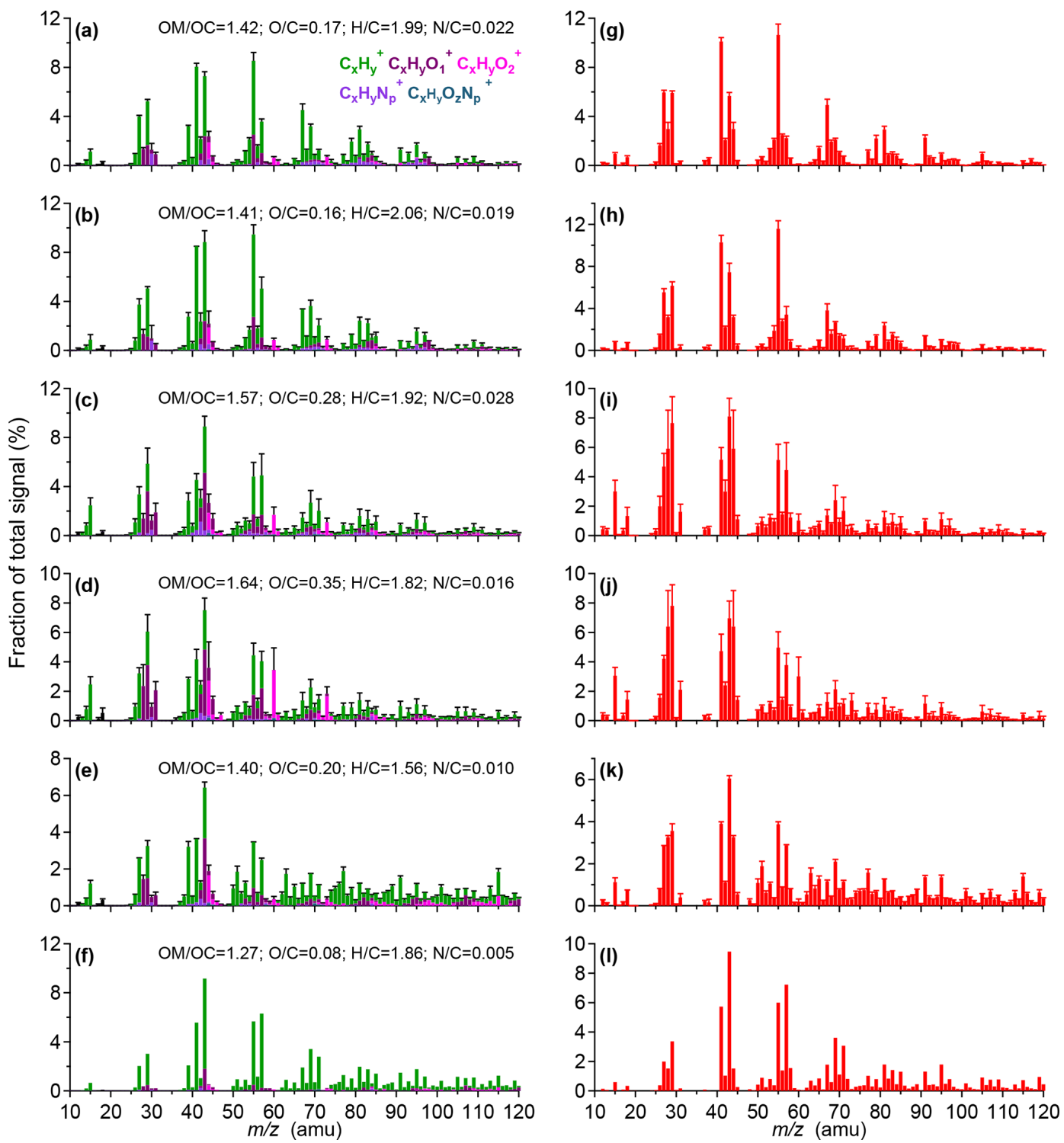

Figure 3. Average mass spectral profiles of OA measured by (a-f) SV-AMS and (g-l) CV-ACSM including (a, g) cooking emissions from vegetable oil, (b, h) from animal oil, (c, i) from crop straw burning, (d, j) from wood burning, and (e), (k) and (f), (l) from smoldering and flaming combustion of bituminous coal, respectively. The error bars represent 1 standard deviation. The elemental composition of OA and WSOA from SV-AMS is also shown. The detailed mass spectra for each type of cooking and burning are presented in Fig. S3.

still lower than that $(\mathrm{O} / \mathrm{C}=0.59)$ identified in winter in urban Beijing (Qiu et al., 2019). These results further suggest that WSOA contains more oxygenated organic compounds with higher oxidation degrees.

\subsection{Wood burning}

Crop straw burning contributes dominantly to BBOA in China during both harvest season and winter (Chen et al., 2017; Sun et al., 2016b), while wood burning is more important for domestic heating in European countries (Mohr et al., 2011; Alfarra et al., 2007). Here we found that the mass spectra of BBOA and wood burning OA (WBOA) show relatively similar features (Fig. 3), which are both characterized by the prominent signals of $m / z 60$ and $m / z$ 73. The $f_{60} / f_{73}$ varies from 1 to 2 for WBOA and BBOA, which is larger than that in cooking emissions $\left(f_{60} / f_{73}=\sim 1\right)$ and CCOA $\left(f_{60} / f_{73}<1\right.$, Fig. 6$)$. Compared to crop straw burning, WBOA of SV-AMS generally shows much higher $f_{60}$ $(2.5-5.7$ vs. $0.8 \%-2.6 \%)$ and $f_{73}(1.3-2.3$ vs. $0.6 \%-1.4 \%)$ and higher oxidation degree with higher $f_{44}(1.7-5.5$ vs. 1.8 $3.4 \%)$ and $\mathrm{O} / \mathrm{C}(0.23-0.51$ vs. $0.16-0.38)$. These results suggest that wood burning appears to produce more anhydrosugar compounds. Consistent with BBOA, WBOA of CVACSM shows much higher $f_{44}$ and slightly lower $f_{60}$ than 

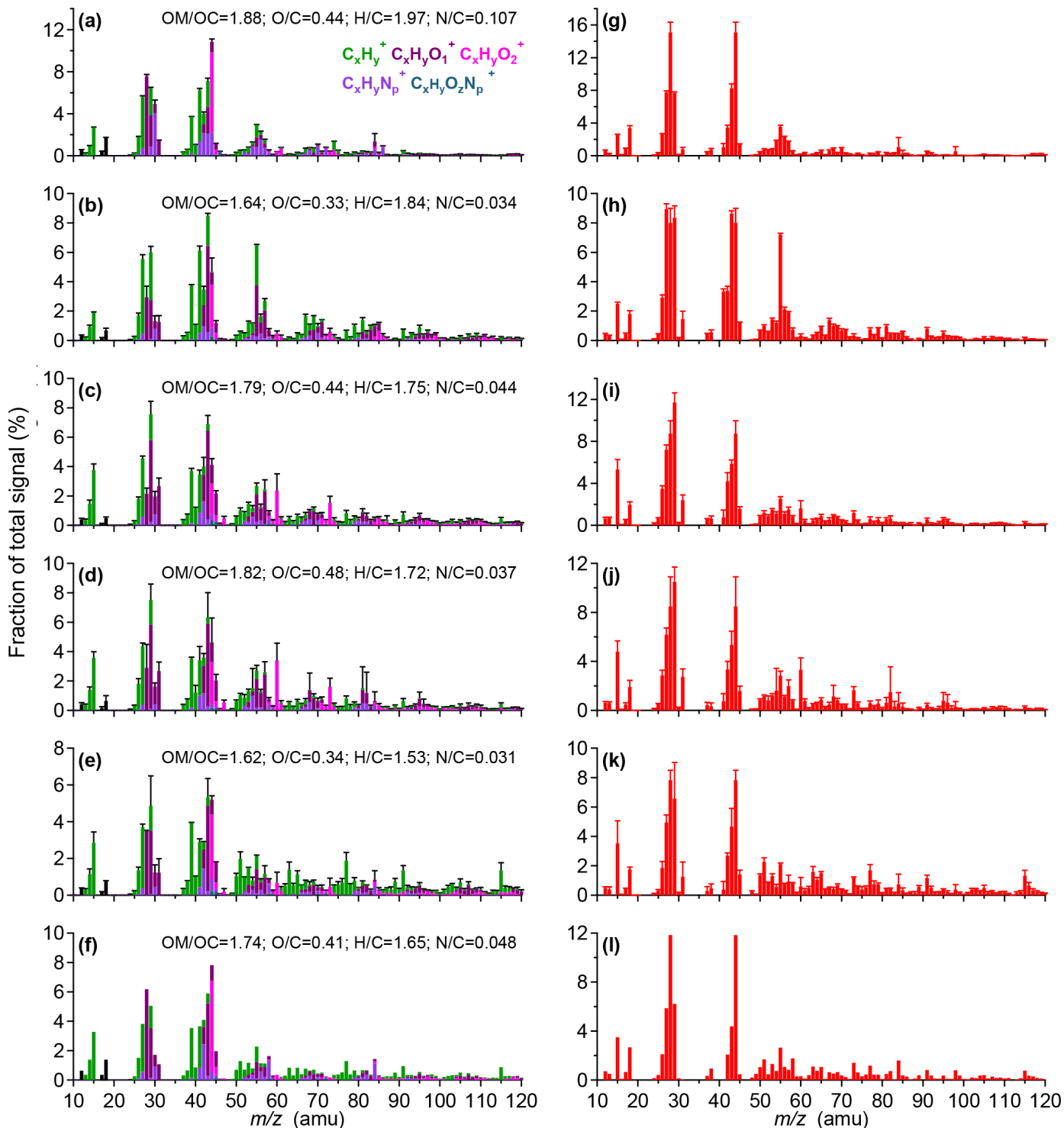

Figure 4. Average mass spectral profiles of WSOA measured by (a-f) SV-AMS and (g-l) CV-ACSM including (a, g) cooking emissions from vegetable oil, $(\mathbf{b}, \mathbf{h})$ from animal oil, $(\mathbf{c}, \mathbf{i})$ from crop straw burning, $(\mathbf{d}, \mathbf{j})$ from wood burning, and (e), (k) and (f), (l) from smoldering and flaming combustion of bituminous coal, respectively. The error bars represent 1 standard deviation. The elemental composition of OA and WSOA from SV-AMS is also shown. The detailed mass spectra for each type of cooking and burning are presented in Fig. S3.

that of SV-AMS (Figs. 3 and S3). However, considering the spectral similarities between BBOA and WBOA, it would be very challenging to separate the two different biomass burning OAs based only on AMS or ACSM measurements.

The mass spectra of WBOA of CV-ACSM show highly similar characteristics to those of SV-AMS $\left(R^{2}=0.88\right.$ 0.94 ), although $f_{60}$ is slightly lower and $f_{44}$ is comparably higher. Similar to BBOA, the water-soluble WBOA is also characterized by prominent peaks of $\mathrm{m} / \mathrm{z} 60$ and $\mathrm{m} / z .73$ (Figs. 3 and S3) and enriched in oxygenated and nitrogen-containing organic compounds $(\mathrm{O} / \mathrm{C}=0.36-0.54$ and $\mathrm{N} / \mathrm{C}=0.016-0.076$ ). In fact, a large fraction of $\mathrm{OC}$ from wood burning was found to be water-soluble (32\%-40\%).
The $f_{44}$ vs. $f_{60}$ plot has been widely used in both field and laboratory studies to characterize the aging of biomass burning OA (Cubison et al., 2011; Hennigan et al., 2011). Photochemical aging of BBOA can be rapid under typical ambient OH levels, e.g., $1 \times 10^{6}$ molec. $\mathrm{cm}^{-3}$ (Hennigan et al., 2010), and BBOA evolves quickly from the right bottom to left top region in $f_{44}$ vs. $f_{60}$, which is characterized by an increase in $f_{44}$ and a corresponding decrease in $f_{60}$. Although $f_{60}$ and $f_{44}$ of CV-ACSM and water-soluble BBOA-WBOA have differences compared with those measured by SV-AMS, the evolving trends in $f_{44}$ vs. $f_{60}$ are similar (Fig. 6). These results suggest that $f_{44}$ vs. $f_{60}$ can also be used as a good diagnostic for chemical aging of biomass burning aerosols 

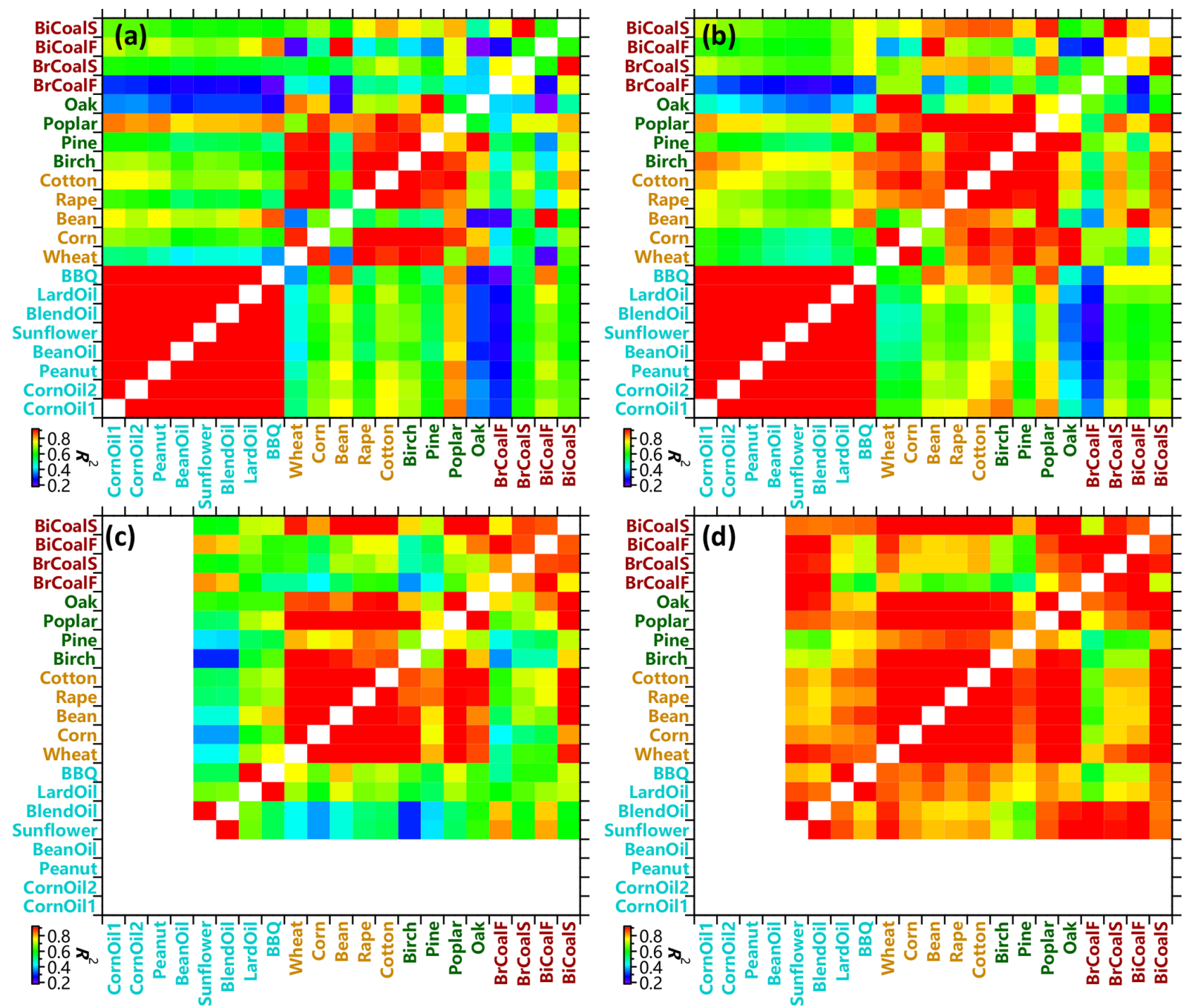

Figure 5. Mass spectral correlations of OA measured by (a) SV-AMS and (b) CV-ACSM and WSOA measured by (c) SV-AMS and (d) CVACSM. The detailed descriptions of cooking and burning fuels are presented in Table S3.

that are measured by the CV-AMS-ACSM. It should be noted that some previous studies also found large differences in $f_{60}$ between SV-AMS and CV-AMS. For example, $\mathrm{Hu}$ et al. (2018a) found that the $f_{60}$ of OA from CV-AMS was lower than that from SV-AMS by a factor of 5 during a period with significant $\mathrm{BB}$ impacts, yet the correlation was high $(R=0.70)$. One explanation is that the thermal decomposition of OA in CV could vary among different instruments, but the aging trends are similar between SV- and CV-AMS.

\subsection{Coal combustion}

Coal combustion emission is one of the most important primary sources of OA in winter in north China (Sun et al., 2013). Although CCOA was resolved and quantified by SVAMS in several previous studies (Sun et al., 2016a; Hu et al., 2013), it becomes more challenging to separate it from traffic-related HOA in megacities of China due to their rela- tively similar mass spectra and diurnal variations. By burning two different types of coals, i.e., brown and bituminous coals under flaming and smoldering conditions, we found that the differences in CCOA spectra of SV-AMS can be substantial under different burning conditions, while the spectra are relatively similar under smoldering conditions $\left(R^{2}=0.98\right.$, Fig. 5). Consistent with previously resolved CCOA in ambient aerosol, the CCOA source spectra are all characterized by prominent hydrocarbon ions (for example, $m / z 41$, $m / z 43, m / z 55$, and $m / z$ 57) and fragments related to polycyclic aromatic hydrocarbons (PAHs), e.g., $m / z$ 152, $m / z 165, m / z 178, m / z 189, m / z 202, m / z 215$. It is interesting to note that the CCOA spectrum in Beijing (Sun et al., 2016a) resembles more that of flaming combustion of bituminous coal, while that observed at Changdao island in central eastern China (Hu et al., 2013) shows more similarity to that of smoldering combustion of bituminous 

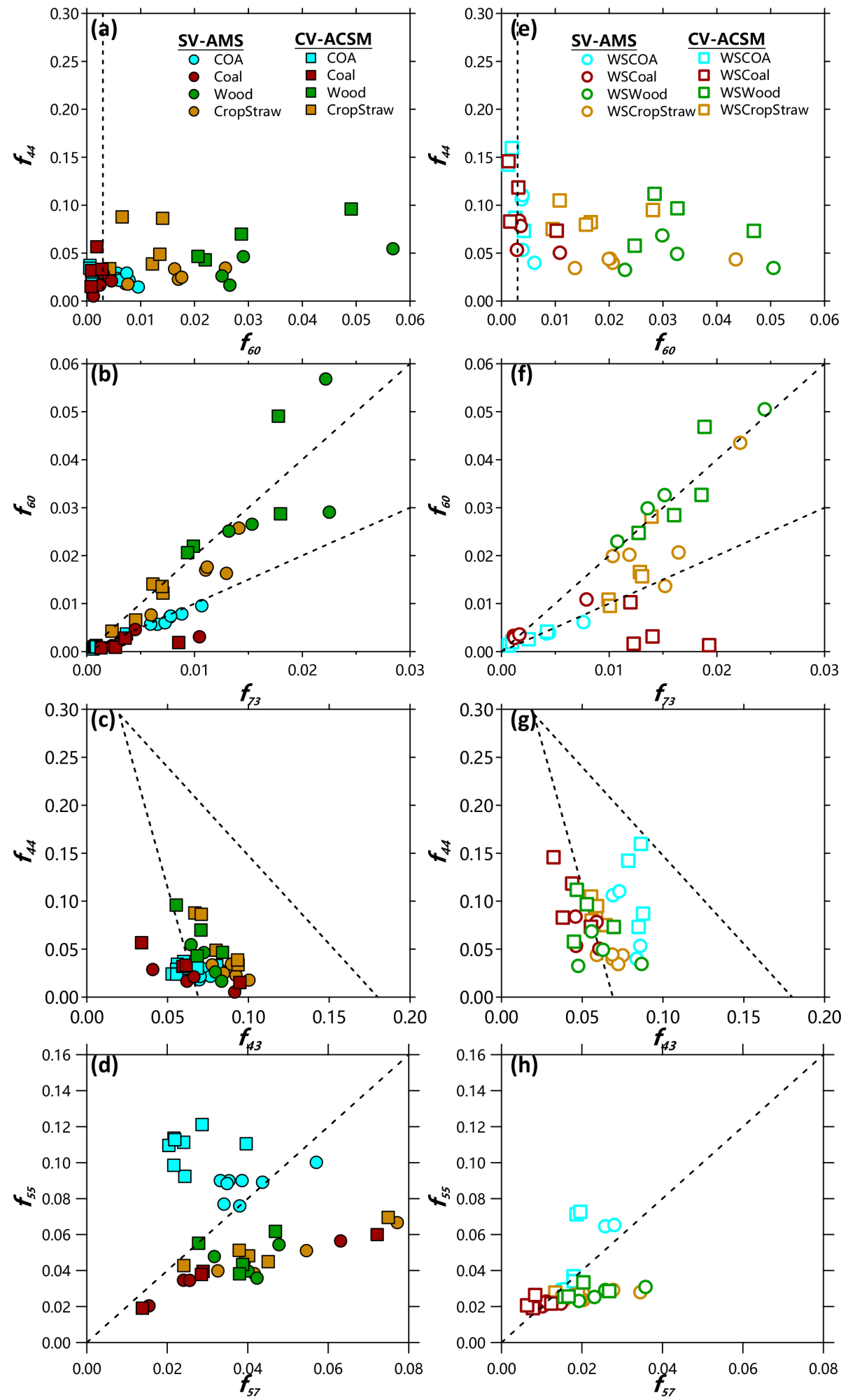

Figure 6. Scatter plots of (a, e) $f_{44}$ vs. $f_{60},(\mathbf{b}, \mathbf{f}) f_{60}$ vs. $f_{73},(\mathbf{c}, \mathbf{g}) f_{44}$ vs. $f_{43}$, and $(\mathbf{d}, \mathbf{h}) f_{55}$ vs. $f_{57}$ for OA (a-f) and WSOA (c-h) from SV-AMS and CV-ACSM measurements. 


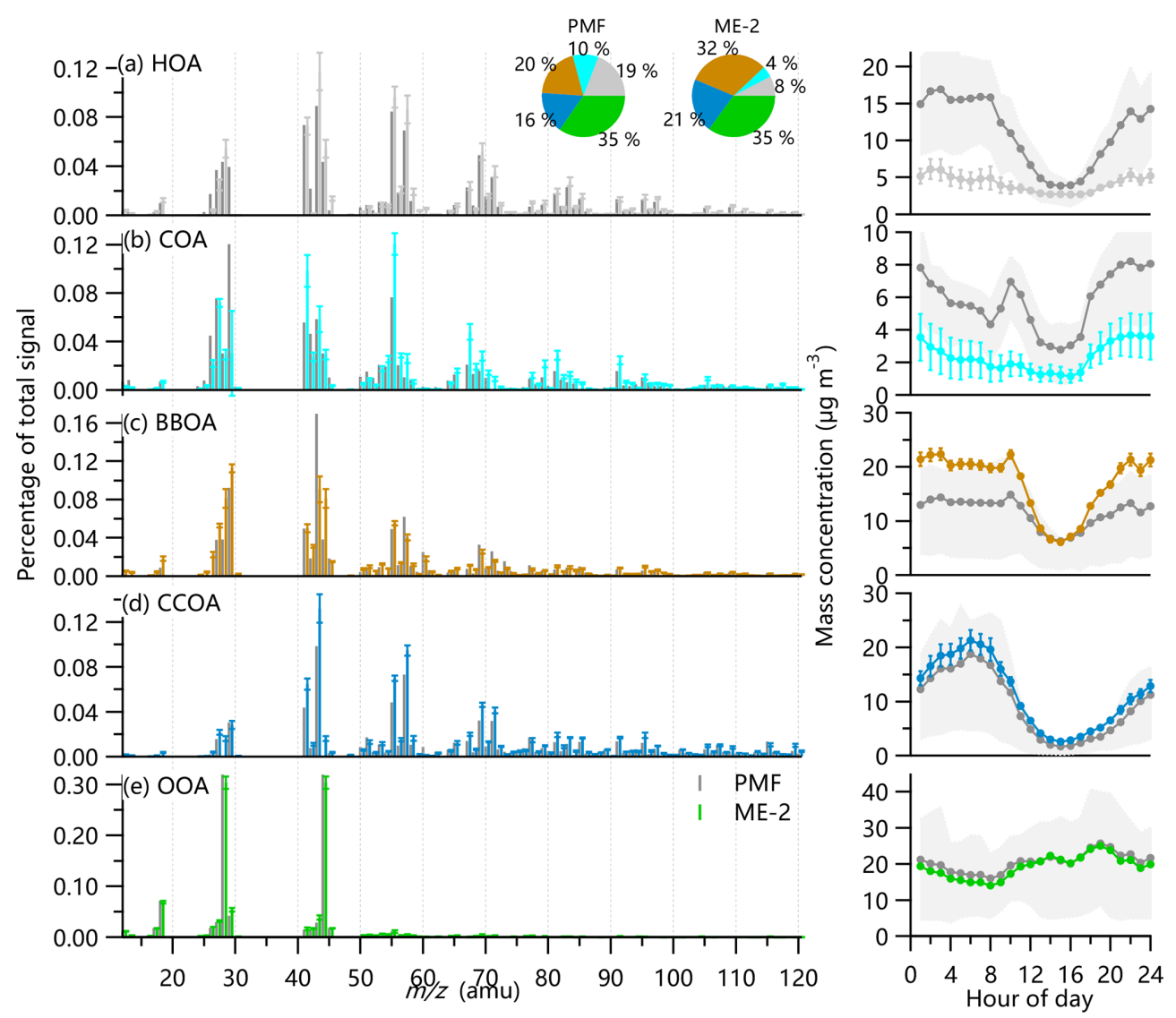

Figure 7. Comparisons of mass spectral profiles, diurnal cycles, and compositions of five OA factors between PMF and ME-2 analysis at a rural site in the North China Plain in winter. The ME- 2 results are the averages with an $\alpha$-value ranging from 0 to 0.3 , and the error bars are 1 standard deviation. The shaded areas in the right panel indicate the 25th and 75th percentiles of PMF results.

coal. This is consistent with the fact that the bituminous coal accounted for $\sim 78 \%$ of the total coal production according to the China Coal Industry Yearbook (Zhou et al., 2016), yet the CCOA emissions can be different in different areas due to different combustion conditions. We also noticed that the signals of $m / z$ 's $>150$ contribute approximately $\sim 40 \%$ of the total signal of CCOA measured by SV-AMS (Fig. S8), which is much higher than those in crop straw-wood burning and cooking emissions, suggesting that CCOA contains much higher fractions of high-molecularweight organic compounds, e.g., PAHs. Therefore, source apportionment studies in regions with large influences of coal combustion emissions need to be cautious. For example, PMF analysis of high-resolution mass spectra of OA by limiting $m / z$ to 150 could underestimate CCOA substantially. Considering that the contribution of CCOA to OA is $\sim 20 \%$ during wintertime in Beijing (Sun et al., 2016a), the missed $m / z$ 's $>150$ in PMF analysis could cause an underestimation of coal combustion by $\sim 8 \%$.

Similar to COA and BBOA, the CCOA spectra of CVACSM resemble those of SV-AMS (Fig. S6), yet with much higher $f_{44}$. Although the thermal decomposition and the in- creased residence time in $\mathrm{CV}$ result in the larger fragments shifting towards smaller ions, the PAH signals are well retained in the mass spectra of CV-ACSM (e.g., $m / z 152$, $m / z 165, m / z 178, m / z 189, m / z 202, m / z 215)$ due to the stabilized chemical structures of PAHs that are very resistant to fragmentation after ionization (McLafferty and Turecek, 1993), consistent with the observations of PAHs from burning different types of coals (Zheng et al., 2020). These results indicate that PAHs can also be used as tracers to identify the coal combustion OA measured by CV-ACSM. We also observed the differences in $f_{44}$ produced from flaming and smoldering combustion. While the flaming combustion of brown coal produced higher $f_{44}$ than smoldering for both SV-AMS and CV-ACSM (5.7 vs. $2.9 \%$ and 3.2 vs. $1.7 \%$, respectively), it was reversed for bituminous coal burning. Previous studies showed that the CCOA spectra evolved during the combustion process depending on the burning temperature and oxygen supplied (Wang et al., 2013). In addition, $f_{60}$ was only observed to be significant in smoldering combustion of bituminous coal $(0.46 \%$, Fig. S3), suggesting that coal combustion can be a potential source of levoglucosan. For instance, Yan et al. (2018) observed the emissions of 
levoglucosan from semi-anthracite burning while mediumand high-volatility bituminous coals appear to be negligible sources.

The $\mathrm{O} / \mathrm{C}$ ratios of coal combustion $\mathrm{OA}$ are generally low, ranging from 0.08 to 0.23 , which are close to those $(0.14$ 0.22 ) identified in ambient air in winter and spring (Xu et al., 2019; Sun et al., 2016a; Hu et al., 2013). The low O/C ratios suggest relatively low water solubility of CCOA. Indeed, the WSOC from the four different types of coal combustion on average accounted for $16-34 \%$ of the total OC, with the flaming combustion generating more water-soluble organic compounds (24-34\%). As a result, the O/C ratios of watersoluble CCOA are approximately twice those of CCOA, and consistently the contributions of oxygenated ions $(36.9 \%-$ $49.7 \%$ ) are much higher. As shown in Fig. S3, the mass spectra of water-soluble CCOA are quite different from the total CCOA, especially for flaming combustion of bituminous coal $\left(R^{2}=0.24\right)$. Although the signals of high $m / z$ 's are largely decreased in the mass spectra of water-soluble CCOA, the spectral characteristics of PAHs (e.g., $m / z 115$, $128,139,152,165,181)$ are still observed (Fig. S9). Because of the reduced signals for large $m / z$ 's, the spectral correlations between water-soluble CCOA and other water-soluble primary OA are much elevated (Fig. 5), increasing the difficulties for the identification of water-soluble CCOA. For example, the spectrum of water-soluble CCOA identified in winter in our previous study was much different from those measured in this study (Qiu et al., 2019), and the O/C ratio (0.68) was also much higher. One reason is likely due to the aging of CCOA during the transport to Beijing because of the ban on coal burning in the city. The uncertainties in PMF analysis caused by the spectra could be another possibility.

\section{Conclusion and implications}

The Aerodyne AMS and ACSM have been widely used to measure OA worldwide, and the subsequent source apportionment of OA by PMF or a ME-2 relies largely upon the mass spectral profiles of primary emissions. While the mass spectra of primary emissions, e.g., cooking, biomass burning, and traffic, are relatively well characterized by SV-AMS, their behaviors in the newly developed CV-AMS and CVACSM are poorly known. Considering the rapid increases in deployments of CV-ACSM and the studies on water-soluble OA worldwide, it is of critical importance to further characterize the mass spectra of primary emissions with $\mathrm{CV}$ ACSM for a better source apportionment of OA in the future. In addition, the mass spectra of OA from coal combustion emissions, one of the most important primary sources in winter in China, are rarely characterized. By measuring 21 different primary emissions with SV-AMS and CV-ACSM, the similar spectral characteristics of primary OA between CV-ACSM and SV-AMS are demonstrated, yet the changes in specific marker $m / z$ 's (e.g., $\left.f_{44}, f_{43}, f_{60}, f_{73}\right)$ and $m / z$ ratios $\left(f_{55} / f_{57}, f_{41} / f_{43}, f_{60} / f_{73}\right.$, etc. $)$ for source diagnostics are also observed due to additional thermal decomposition in CV. Among all primary emissions, we found that the COA spectrum is the most robust for both SV-AMS and CVACSM and has no clear dependence on oil gradients. However, the spectral differences between water-soluble OA and the total OA can be substantial for both SV-AMS and CVACSM depending on water solubility, which is in the order of $\mathrm{BBOA}>\mathrm{WBOA}>\mathrm{COA}>\mathrm{CCOA}$. Note that the mass loadings of primary emissions in this experiment are much higher than those in ambient air, which could cause some differences in water solubility and subsequent spectral differences in WSOA. In addition, we found that mass spectra of WSOA from CV-ACSM are relatively well correlated among different primary emissions, highlighting the challenges in source apportionment of WSOA using CV-ACSM in the future.

We further demonstrate the importance of mass spectra of primary emissions for OA source apportionment in a field campaign that was conducted with a $\mathrm{PM}_{2.5} \mathrm{CV}-\mathrm{ACSM}$ at a highly polluted rural site in the North China Plain in winter (Kuang et al., 2020). Positive matrix factorization of OA was able to identify four primary OA factors including traffic-related $\mathrm{HOA}, \mathrm{COA}, \mathrm{BBOA}$, and $\mathrm{CCOA}$ and one secondary OOA. We found that the average contributions of HOA and COA (19\% and $16 \%$, respectively) were much higher than expected because the rural site is far from urban areas $(\sim 15 \mathrm{~km})$ and tends to have small influences from cooking and traffic emissions. Although the temporal variations appeared to be reasonable and were correlated with specific tracer species (e.g., BC and $\mathrm{CO}$ ), the COA spectrum showed unrealistically higher $m / z 27$ and $m / z$ 29, and BBOA and CCOA spectra showed much lower $f_{44}$ than those observed in source profiles (Fig. 7). Therefore, we reperformed the OA source apportionment with a ME-2 by constraining four primary OA factors. Considering the chemical environment of the sampling site, we used the average mass spectra of COA from vegetable oil, flaming combustion of bituminous coal, crop straw burning of corn, and HOA resolved in Rizhao city by the same CV-ACSM as in this study in September (Lei et al., 2019) as constraints in ME-2 analysis with an $\alpha$-value ranging from 0 to 0.3 . As shown in Fig. 7, the ME- 2 results showed much reduced HOA and COA contributions ( $8 \%$ and $5 \%$, respectively) compared with those from PMF analysis. As a result, BBOA and CCOA became the two major primary sources at the rural site in the North China Plain (32\% and $21 \%$, respectively), consistent with the fact that coal and crop straw are the major fuels for residential heating. Also, the unrealistically high morning COA peak in PMF analysis disappeared in the ME-2 analysis, further supporting the rationale of $\mathrm{ME}-2$ results (Fig. 7). Although the average contributions of POA and SOA are very close with and without constraining POA spectral profiles, the apportionment of POA factors can be improved substantially. The accurate source apportionment results have significant implications for future air pollution mitigation strate- 
gies; for instance, our new results highlight that reducing coal combustion and biomass burning emissions would be the most effective measure to improve the winter air quality in rural areas in the North China Plain.

Data availability. The mass spectra of CV-ToF-ACSM are available at http://cires1.colorado.edu/jimenez-group/AMSsd_CV/ (Hu et al., 2018c). Other data in this study are available from the authors upon request (sunyele@mail.iap.ac.cn).

Supplement. The supplement related to this article is available online at: https://doi.org/10.5194/amt-13-3205-2020-supplement.

Author contributions. YS, QW, and $\mathrm{YH}$ designed the research. QW, YH, YQ, CC, LL, and ZL conducted the experiments. LL, QW, YH, and YQ analyzed the data. YJ, PF, ZW, and DW reviewed and commented on the paper. QW, YH, and YS wrote the paper.

Competing interests. The authors declare that they have no conflict of interest.

Financial support. This research has been supported by the National Natural Science Foundation of China (grant nos. 41975170, 91744207).

Review statement. This paper was edited by Mingjin Tang and reviewed by two anonymous referees.

\section{References}

Alfarra, M. R., Prevot, A. S. H., Szidat, S., Sandradewi, J., Weimer, S., Lanz, V. A., Schreiber, D., Mohr, M., and Baltensperger, U.: Identification of the mass spectral signature of organic aerosols from wood burning emissions, Environ. Sci. Technol., 41, 57705777, 2007.

Allan, J. D., Williams, P. I., Morgan, W. T., Martin, C. L., Flynn, M. J., Lee, J., Nemitz, E., Phillips, G. J., Gallagher, M. W., and Coe, H.: Contributions from transport, solid fuel burning and cooking to primary organic aerosols in two UK cities, Atmos. Chem. Phys., 10, 647-668, https://doi.org/10.5194/acp-10-6472010, 2010.

Bahreini, R., Ervens, B., Middlebrook, A. M., Warneke, C., de Gouw, J. A., DeCarlo, P. F., Jimenez, J. L., Brock, C. A., Neuman, J. A., Ryerson, T. B., Stark, H., Atlas, E., Brioude, J., Fried, A., Holloway, J. S., Peischl, J., Richter, D., Walega, J., Weibring, P., Wollny, A. G., and Fehsenfeld, F. C.: Organic aerosol formation in urban and industrial plumes near Houston and Dallas, Texas, J. Geophys. Res.-Atmos., 114, D00f16, https://doi.org/10.1029/2008jd011493, 2009.

Bottenus, C. L. H., Massoli, P., Sueper, D., Canagaratna, M. R., VanderSchelden, G., Jobson, B. T., and VanReken, T. M.: Identi- fication of amines in wintertime ambient particulate material using high resolution aerosol mass spectrometry, Atmos. Environ., 180, 173-183, https://doi.org/10.1016/j.atmosenv.2018.01.044, 2018.

Bozzetti, C., El Haddad, I., Salameh, D., Daellenbach, K. R., Fermo, P., Gonzalez, R., Minguillón, M. C., Iinuma, Y., Poulain, L., Elser, M., Müller, E., Slowik, J. G., Jaffrezo, J.L., Baltensperger, U., Marchand, N., and Prévôt, A. S. H.: Organic aerosol source apportionment by offline-AMS over a full year in Marseille, Atmos. Chem. Phys., 17, 8247-8268, https://doi.org/10.5194/acp-17-8247-2017, 2017.

Canagaratna, M., Jayne, J., Jimenez, J. L., Allan, J. A., Alfarra, R., Zhang, Q., Onasch, T., Drewnick, F., Coe, H., Middlebrook, A., Delia, A., Williams, L., Trimborn, A., Northway, M., Kolb, C., Davidovits, P., and Worsnop, D.: Chemical and microphysical characterization of aerosols via Aerosol Mass Spectrometry, Mass Spectrom. Rev., 26, 185-222, 2007.

Canagaratna, M. R., Jayne, J. T., Ghertner, D. A., Herndon, S., Shi, Q., Jimenez, J. L., Silva, P. J., Williams, P., Lanni, T., Drewnick, F., Demerjian, K. L., Kolb, C. E., and Worsnop, D. R.: Chase studies of particulate emissions from in-use New York City vehicles, Aerosol Sci. Tech., 38, 555-573, 2004.

Canagaratna, M. R., Jimenez, J. L., Kroll, J. H., Chen, Q., Kessler, S. H., Massoli, P., Hildebrandt Ruiz, L., Fortner, E., Williams, L. R., Wilson, K. R., Surratt, J. D., Donahue, N. M., Jayne, J. T., and Worsnop, D. R.: Elemental ratio measurements of organic compounds using aerosol mass spectrometry: characterization, improved calibration, and implications, Atmos. Chem. Phys., 15, 253-272, https://doi.org/10.5194/acp-15-253-2015, 2015.

Chen, J., Li, C., Ristovski, Z., Milic, A., Gu, Y., Islam, M. S., Wang, S., Hao, J., Zhang, H., and He, C.: A review of biomass burning: Emissions and impacts on air quality, health and climate in China, Sci. Total Environ., 579, 1000-1034, 2017.

Collier, S., Zhou, S., Kuwayama, T., Forestieri, S., Brady, J., Zhang, M., Kleeman, M., Cappa, C., Bertram, T., and Zhang, Q.: Organic PM Emissions from Vehicles: Composition, O/C Ratio, and Dependence on PM Concentration, Aerosol Sci. Tech., 49, 86-97, https://doi.org/10.1080/02786826.2014.1003364, 2015.

Collier, S., Zhou, S., Onasch, T. B., Jaffe, D. A., Kleinman, L., Sedlacek, A. J., Briggs, N. L., Hee, J., Fortner, E., Shilling, J. E., Worsnop, D., Yokelson, R. J., Parworth, C., Ge, X., Xu, J., Butterfield, Z., Chand, D., Dubey, M. K., Pekour, M. S., Springston, S., and Zhang, Q.: Regional Influence of Aerosol Emissions from Wildfires Driven by Combustion Efficiency: Insights from the BBOP Campaign, Environ. Sci. Technol., 50, 8613-8622, https://doi.org/10.1021/acs.est.6b01617, 2016.

Cubison, M. J., Ortega, A. M., Hayes, P. L., Farmer, D. K., Day, D., Lechner, M. J., Brune, W. H., Apel, E., Diskin, G. S., Fisher, J. A., Fuelberg, H. E., Hecobian, A., Knapp, D. J., Mikoviny, T., Riemer, D., Sachse, G. W., Sessions, W., Weber, R. J., Weinheimer, A. J., Wisthaler, A., and Jimenez, J. L.: Effects of aging on organic aerosol from open biomass burning smoke in aircraft and laboratory studies, Atmos. Chem. Phys., 11, 12049-12064, https://doi.org/10.5194/acp-11-12049-2011, 2011.

Daellenbach, K. R., Bozzetti, C., Křepelová, A., Canonaco, F., Wolf, R., Zotter, P., Fermo, P., Crippa, M., Slowik, J. G., Sosedova, Y., Zhang, Y., Huang, R.-J., Poulain, L., Szidat, S., Baltensperger, U., El Haddad, I., and Prévôt, A. S. H.: Characterization and source apportionment of organic aerosol using of- 
fline aerosol mass spectrometry, Atmos. Meas. Tech., 9, 23-39, https://doi.org/10.5194/amt-9-23-2016, 2016.

Desyaterik, Y., Sun, Y., Shen, X., Lee, T., Wang, X., Wang, T., and Collett Jr., J. L.: Speciation of "brown" carbon in cloud water impacted by agricultural biomass burning in eastern China, J. Geophys. Res.-Atmos., 118, 7389-7399, https://doi.org/10.1002/jgrd.50561, 2013.

Donahue, N. M., Robinson, A. L., Stanier, C. O., and Pandis, S. N.: Coupled partitioning, dilution, and chemical aging of semivolatile organics, Environ. Sci. Technol., 40, 2635-2643, 2006.

Faber, P., Drewnick, F., Veres, P. R., Williams, J., and Borrmann, S.: Anthropogenic sources of aerosol particles in a football stadium: Real-time characterization of emissions from cigarette smoking, cooking, hand flares, and color smoke bombs by high-resolution aerosol mass spectrometry, Atmos. Environ., 77, 1043-1051, https://doi.org/10.1016/j.atmosenv.2013.05.072, 2013.

Fang, Z., Deng, W., Zhang, Y., Ding, X., Tang, M., Liu, T., Hu, Q., Zhu, M., Wang, Z., Yang, W., Huang, Z., Song, W., Bi, X., Chen, J., Sun, Y., George, C., and Wang, X.: Open burning of rice, corn and wheat straws: primary emissions, photochemical aging, and secondary organic aerosol formation, Atmos. Chem. Phys., 17, 14821-14839, https://doi.org/10.5194/acp-17-148212017, 2017.

Gilardoni, S., Massoli, P., Paglione, M., Giulianelli, L., Carbone, C., Rinaldi, M., Decesari, S., Sandrini, S., Costabile, F., Gobbi, G. P., Pietrogrande, M. C., Visentin, M., Scotto, F., Fuzzi, S., and Facchini, M. C.: Direct observation of aqueous secondary organic aerosol from biomassburning emissions, P. Natl. Acad. Sci. USA, 113, 10013-10018, https://doi.org/10.1073/pnas.1602212113, 2016.

He, L.-Y., Lin, Y., Huang, X.-F., Guo, S., Xue, L., Su, Q., Hu, M., Luan, S.-J., and Zhang, Y.-H.: Characterization of highresolution aerosol mass spectra of primary organic aerosol emissions from Chinese cooking and biomass burning, Atmos. Chem. Phys., 10, 11535-11543, https://doi.org/10.5194/acp-10-115352010, 2010.

Hennigan, C. J., Sullivan, A. P., Collett, J. L., and Robinson, A. L.: Levoglucosan stability in biomass burning particles exposed to hydroxyl radicals, Geophys. Res. Lett., 37, L09806, https://doi.org/10.1029/2010GL043088, 2010.

Hennigan, C. J., Miracolo, M. A., Engelhart, G. J., May, A. A., Presto, A. A., Lee, T., Sullivan, A. P., McMeeking, G. R., Coe, H., Wold, C. E., Hao, W.-M., Gilman, J. B., Kuster, W. C., de Gouw, J., Schichtel, B. A., Collett Jr., J. L., Kreidenweis, S. M., and Robinson, A. L.: Chemical and physical transformations of organic aerosol from the photo-oxidation of open biomass burning emissions in an environmental chamber, Atmos. Chem. Phys., 11, 7669-7686, https://doi.org/10.5194/acp11-7669-2011, 2011.

Hu, W., Campuzano-Jost, P., Day, D. A., Croteau, P., Canagaratna, M. R., Jayne, J. T., Worsnop, D. R., and Jimenez, J. L.: Evaluation of the new capture vaporizer for aerosol mass spectrometers (AMS) through field studies of inorganic species, Aerosol Sci. Tech., 51, 735-754, https://doi.org/10.1080/02786826.2017.1296104, 2017.

Hu, W., Day, D. A., Campuzano-Jost, P., Nault, B. A., Park, T., Lee, T., Croteau, P., Canagaratna, M. R., Jayne, J. T., Worsnop, D. R., and Jimenez, J. L.: Evaluation of the new capture va- porizer for aerosol mass spectrometers: Characterization of organic aerosol mass spectra, Aerosol Sci. Tech., 52, 725-739, https://doi.org/10.1080/02786826.2018.1454584, 2018a.

Hu, W., Day, D. A., Campuzano-Jost, P., Nault, B. A., Park, T., Lee, T., Croteau, P., Canagaratna, M. R., Jayne, J. T., Worsnop, D. R., and Jimenez, J. L.: Evaluation of the New Capture Vaporizer for Aerosol Mass Spectrometers (AMS): Elemental Composition and Source Apportionment of Organic Aerosols (OA), ACS Earth and Space Chemistry, 2, 410-421, https://doi.org/10.1021/acsearthspacechem.8b00002, 2018b.

Hu, W., Handschy, A., and Jimenez, J. L.: AMS Capture Vaporizer Spectral Database, http://cires1.colorado.edu/ jimenez-group/AMSsd_CV/ (last access: 6 June 2020), 2018c.

Hu, W. W., Hu, M., Yuan, B., Jimenez, J. L., Tang, Q., Peng, J. F., Hu, W., Shao, M., Wang, M., Zeng, L. M., Wu, Y. S., Gong, Z. H., Huang, X. F., and He, L. Y.: Insights on organic aerosol aging and the influence of coal combustion at a regional receptor site of central eastern China, Atmos. Chem. Phys., 13, 10095-10112, https://doi.org/10.5194/acp-13-10095-2013, 2013.

Huffman, J. A., Jayne, J. T., Drewnick, F., Aiken, A. C., Onasch, T., Worsnop, D. R., and Jimenez, J. L.: Design, modeling, optimization, and experimental tests of a particle beam width probe for the Aerodyne Aerosol Mass Spectrometer, Aerosol Sci. Tech., 39, 1143-1163, 2005

Kaltsonoudis, C., Kostenidou, E., Louvaris, E., Psichoudaki, M., Tsiligiannis, E., Florou, K., Liangou, A., and Pandis, S. N.: Characterization of fresh and aged organic aerosol emissions from meat charbroiling, Atmos. Chem. Phys., 17, 7143-7155, https://doi.org/10.5194/acp-17-7143-2017, 2017.

Kuang, Y., He, Y., Xu, W., Zhao, P., Cheng, Y., Zhao, G., Tao, J., Ma, N., Su, H., Zhang, Y., Sun, J., Cheng, P., Yang, W., Zhang, S., Wu, C., Sun, Y., and Zhao, C.: Distinct diurnal variation in organic aerosol hygroscopicity and its relationship with oxygenated organic aerosol, Atmos. Chem. Phys., 20, 865-880, https://doi.org/10.5194/acp-20-865-2020, 2020.

Laskin, A., Smith, J. S., and Laskin, J.: Molecular characterization of nitrogen-containing organic compounds in biomass burning aerosols using high-resolution mass spectrometry, Environ. Sci. Technol., 43, 3764-3771, https://doi.org/10.1021/es803456n, 2009.

Lee, T., Sullivan, A. P., Mack, L., Jimenez, J. L., Kreidenweis, S. M., Onasch, T. B., Worsnop, D. R., Malm, W., Wold, C. E., Hao, W. M., and Collett, J. L.: Chemical Smoke Marker Emissions During Flaming and Smoldering Phases of Laboratory Open Burning of Wildland Fuels, Aerosol Sci. Tech., 44, 1-5, 2010.

Lei, L., Xie, C., Wang, D., He, Y., Wang, Q., Zhou, W., Hu, W., Fu, P., Chen, Y., Pan, X., Wang, Z., Worsnop, D. R., and Sun, Y.: Fine particle characterization in a coastal city in China: composition, sources, and impacts of industrial emissions, Atmos. Chem. Phys., 20, 2877-2890, https://doi.org/10.5194/acp20-2877-2020, 2020.

Li, L. J., Ren, L. J., Ren, H., Yue, S. Y., Xie, Q. R., Zhao, W. Y., Kang, M. J., Li, J., Wang, Z. F., Sun, Y. L., and Fu, P. Q.: Molecular Characterization and Seasonal Variation in Primary and Secondary Organic Aerosols in Beijing, China, J. Geophys. Res.-Atmos., 123, 12394-12412, https://doi.org/10.1029/2018jd028527, 2018.

Li, Y. J., Sun, Y., Zhang, Q., Li, X., Li, M., Zhou, Z., and Chan, C. K.: Real-time chemical characterization of atmospheric particu- 
late matter in China: A review, Atmos. Environ., 158, 270-304, https://doi.org/10.1016/j.atmosenv.2017.02.027, 2017.

Lin, C., Ceburnis, D., Hellebust, S., Buckley, P., Wenger, J., Canonaco, F., Prévôt, A. S. H., Huang, R.-J., O’Dowd, C., and Ovadnevaite, J.: Characterization of Primary Organic Aerosol from Domestic Wood, Peat, and Coal Burning in Ireland, Environ. Sci. Technol., 51, 10624-10632, https://doi.org/10.1021/acs.est.7b01926, 2017.

Liu, T., Li, Z., Chan, M., and Chan, C. K.: Formation of secondary organic aerosols from gas-phase emissions of heated cooking oils, Atmos. Chem. Phys., 17, 7333-7344, https://doi.org/10.5194/acp-17-7333-2017, 2017.

Liu, T., Wang, Z., Wang, X., and Chan, C. K.: Primary and secondary organic aerosol from heated cooking oil emissions, Atmos. Chem. Phys., 18, 11363-11374, https://doi.org/10.5194/acp-18-11363-2018, 2018.

Matthew, B. M., Middlebrook, A. M., and Onasch, T. B.: Collection Efficiencies in an Aerodyne Aerosol Mass Spectrometer as a Function of Particle Phase for Laboratory Generated Aerosols, Aerosol Sci. Tech., 42, 884-898, 2008.

Mayol-Bracero, O. L., Guyon, P., Graham, B., Roberts, G., Andreae, M. O., Decesari, S., Facchini, M. C., Fuzzi, S., and Artaxo, P.: Water-soluble organic compounds in biomass burning aerosols over Amazonia - 2. Apportionment of the chemical composition and importance of the polyacidic fraction, J. Geophys. Res.-Atmos., 107, 8091, https://doi.org/10.1029/2001JD000522, 2002.

McLafferty, F. W. and Turecek, F.: Interpretation of Mass Spectra, University Science Books, Mill Valley, California, 1993.

Middlebrook, A. M., Bahreini, R., Jimenez, J. L., and Canagaratna, M. R.: Evaluation of Composition-Dependent Collection Efficiencies for the Aerodyne Aerosol Mass Spectrometer using Field Data, Aerosol Sci. Tech., 46, 258-271, https://doi.org/10.1080/02786826.2011.620041, 2012.

Mohr, C., Huffman, J. A., Cubison, M. J., Aiken, A. C., Docherty, K. S., Kimmel, J. R., Ulbrich, I. M., Hannigan, M., and Jimenez, J. L.: Characterization of primary organic aerosol emissions from meat cooking, trash burning, and motor vehicles with HighResolution Aerosol Mass Spectrometry and comparison with ambient and chamber observations, Environ. Sci. Technol., 43, 2443-2449, https://doi.org/10.1021/es8011518, 2009.

Mohr, C., Richter, R., DeCarlo, P. F., Prévôt, A. S. H., and Baltensperger, U.: Spatial variation of chemical composition and sources of submicron aerosol in Zurich during wintertime using mobile aerosol mass spectrometer data, Atmos. Chem. Phys., 11, 7465-7482, https://doi.org/10.5194/acp-11-7465-2011, 2011.

Mohr, C., DeCarlo, P. F., Heringa, M. F., Chirico, R., Slowik, J. G., Richter, R., Reche, C., Alastuey, A., Querol, X., Seco, R., Peñuelas, J., Jiménez, J. L., Crippa, M., Zimmermann, R., Baltensperger, U., and Prévôt, A. S. H.: Identification and quantification of organic aerosol from cooking and other sources in Barcelona using aerosol mass spectrometer data, Atmos. Chem. Phys., 12, 1649-1665, https://doi.org/10.5194/acp-121649-2012, 2012.

Morgan, W. T., Allan, J. D., Bauguitte, S., Darbyshire, E., Flynn, M. J., Lee, J., Liu, D., Johnson, B., Haywood, J., Longo, K. M., Artaxo, P. E., and Coe, H.: Transformation and ageing of biomass burning carbonaceous aerosol over tropical South America from aircraft in situ measurements during SAMBBA, At- mos. Chem. Phys., 20, 5309-5326, https://doi.org/10.5194/acp20-5309-2020, 2020.

Paatero, P.: The multilinear engine - A table-driven, least squares program for solving multilinear problems, including the n-way parallel factor analysis model, J. Comput. Graph. Stat., 8, 854888, 1999.

Paatero, P. and Tapper, U.: Positive matrix factorization: A nonnegative factor model with optimal utilization of error estimates of data values, Environmetrics, 5, 111-126, 1994.

Qiu, Y., Xie, Q., Wang, J., Xu, W., Li, L., Wang, Q., Zhao, J., Chen, Y., Chen, Y., Wu, Y., Du, W., Zhou, W., Lee, J., Zhao, C., Ge, X., Fu, P., Wang, Z., Worsnop, D. R., and Sun, Y.: Vertical Characterization and Source Apportionment of Water-Soluble Organic Aerosol with High-resolution Aerosol Mass Spectrometry in Beijing, China, ACS Earth and Space Chemistry, 3, 273-284, https://doi.org/10.1021/acsearthspacechem.8b00155, 2019.

Reyes-Villegas, E., Bannan, T., Le Breton, M., Mehra, A., Priestley, M., Percival, C., Coe, H., and Allan, J. D.: Online Chemical Characterization of Food-Cooking Organic Aerosols: Implications for Source Apportionment, Environ. Sci. Technol., 52, 5308-5318, https://doi.org/10.1021/acs.est.7b06278, 2018a.

Reyes-Villegas, E., Priestley, M., Ting, Y.-C., Haslett, S., Bannan, T., Le Breton, M., Williams, P. I., Bacak, A., Flynn, M. J., Coe, H., Percival, C., and Allan, J. D.: Simultaneous aerosol mass spectrometry and chemical ionisation mass spectrometry measurements during a biomass burning event in the UK: insights into nitrate chemistry, Atmos. Chem. Phys., 18, 40934111, https://doi.org/10.5194/acp-18-4093-2018, 2018b.

Robinson, E. S., Gu, P. S., Ye, Q., Li, H. Z., Shah, R. U., Apte, J. S., Robinson, A. L., and Presto, A. A.: Restaurant Impacts on Outdoor Air Quality: Elevated Organic Aerosol Mass from Restaurant Cooking with NeighborhoodScale Plume Extents, Environ. Sci. Technol., 52, 9285-9294, https://doi.org/10.1021/acs.est.8b02654, 2018.

Schauer, J. J., Kleeman, M. J., Cass, G. R., and Simoneit, B. R. T.: Measurement of emissions from air pollution sources. 4. $\mathrm{C}_{1}-$ $\mathrm{C}_{27}$ organic compounds from cooking with seed oils, Environ. Sci. Technol., 36, 567-575, 2002.

Schneider, J., Weimer, S., Drewnick, F., Borrmann, S., Helas, G., Gwaze, P., Schmid, O., Andreae, M. O., and Kirchner, U.: Mass spectrometric analysis and aerodynamic properties of various types of combustion-related aerosol particles, Int. J. Mass Spectrom., 258, 37-49, 2006.

Shilling, J. E., Chen, Q., King, S. M., Rosenoern, T., Kroll, J. H., Worsnop, D. R., DeCarlo, P. F., Aiken, A. C., Sueper, D., Jimenez, J. L., and Martin, S. T.: Loading-dependent elemental composition of $\alpha$-pinene SOA particles, Atmos. Chem. Phys., 9, 771-782, https://doi.org/10.5194/acp-9-771-2009, 2009.

Sun, Y., Du, W., Fu, P., Wang, Q., Li, J., Ge, X., Zhang, Q., Zhu, C., Ren, L., Xu, W., Zhao, J., Han, T., Worsnop, D. R., and Wang, Z.: Primary and secondary aerosols in Beijing in winter: sources, variations and processes, Atmos. Chem. Phys., 16, 8309-8329, https://doi.org/10.5194/acp-16-8309-2016, 2016 a.

Sun, Y., Jiang, Q., Xu, Y., Ma, Y., Zhang, Y., Liu, X., Li, W., Wang, F., Li, J., Wang, P., and Li, Z.: Aerosol characterization over the North China Plain: Haze life cycle and biomass burning impacts in summer, J. Geophys. Res.-Atmos., 121, 2508-2521, https://doi.org/10.1002/2015jd024261, 2016b. 
Sun, Y.-L., Zhang, Q., Schwab, J. J., Demerjian, K. L., Chen, W.N., Bae, M.-S., Hung, H.-M., Hogrefe, O., Frank, B., Rattigan, O. V., and Lin, Y.-C.: Characterization of the sources and processes of organic and inorganic aerosols in New York city with a high-resolution time-of-flight aerosol mass apectrometer, Atmos. Chem. Phys., 11, 1581-1602, https://doi.org/10.5194/acp11-1581-2011, 2011.

Sun, Y. L., Wang, Z. F., Fu, P. Q., Yang, T., Jiang, Q., Dong, H. B., Li, J., and Jia, J. J.: Aerosol composition, sources and processes during wintertime in Beijing, China, Atmos. Chem. Phys., 13, 4577-4592, https://doi.org/10.5194/acp-13-4577-2013, 2013.

Wang, X., Williams, B. J., Wang, X., Tang, Y., Huang, Y., Kong, L., Yang, X., and Biswas, P.: Characterization of organic aerosol produced during pulverized coal combustion in a drop tube furnace, Atmos. Chem. Phys., 13, 10919-10932, https://doi.org/10.5194/acp-13-10919-2013, 2013.

Wang, X. F., Gu, R. R., Wang, L. W., Xu, W. X., Zhang, Y. T., Chen, B., Li, W. J., Xue, L. K., Chen, J. M., and Wang, W. X.: Emissions of fine particulate nitrated phenols from the burning of five common types of biomass, Environ. Pollut., 230, 405-412, https://doi.org/10.1016/j.envpol.2017.06.072, 2017.

Weimer, S., Alfarra, M. R., Schreiber, D., Mohr, M., Prévôt, A. S. H., and Baltensperger, U.: Organic aerosol mass spectral signatures from wood-burning emissions: Influence of burning conditions and wood type, J. Geophys. Res, 113, D10304, https://doi.org/10.1029/2007JD009309, 2008.

$\mathrm{Xu}$, L., Guo, H., Weber, R. J., and Ng, N. L.: Chemical Characterization of Water-Soluble Organic Aerosol in Contrasting Rural and Urban Environments in the Southeastern United States, Environ. Sci. Technol., 51, 78-88, https://doi.org/10.1021/acs.est.6b05002, 2017a.

Xu, W., Croteau, P., Williams, L., Canagaratna, M., Onasch, T., Cross, E., Zhang, X., Robinson, W., Worsnop, D., and Jayne, J.: Laboratory characterization of an aerosol chemical speciation monitor with $\mathrm{PM}_{2.5}$ measurement capability, Aerosol Sci. Tech., 51, 69-83, https://doi.org/10.1080/02786826.2016.1241859, $2017 b$.

Xu, W., Han, T., Du, W., Wang, Q., Chen, C., Zhao, J., Zhang, Y., Li, J., Fu, P., Wang, Z., Worsnop, D. R., and Sun, Y.: Effects of Aqueous-Phase and Photochemical Processing on Secondary Organic Aerosol Formation and Evolution in Beijing, China, Environ. Sci. Technol., 51, 762-770, https://doi.org/10.1021/acs.est.6b04498, 2017c.
Xu, W., Sun, Y., Wang, Q., Du, W., Zhao, J., Ge, X., Han, T., Zhang, Y., Zhou, W., Li, J., Fu, P., Wang, Z., and Worsnop, D. R.: Seasonal Characterization of Organic Nitrogen in Atmospheric Aerosols Using High Resolution Aerosol Mass Spectrometry in Beijing, China, ACS Earth and Space Chemistry, 1, 673-682, https://doi.org/10.1021/acsearthspacechem.7b00106, 2017d.

Xu, W., Sun, Y., Wang, Q., Zhao, J., Wang, J., Ge, X., Xie, C., Zhou, W., Du, W., Li, J., Fu, P., Wang, Z., Worsnop, D. R., and Coe, H.: Changes in Aerosol Chemistry From 2014 to 2016 in Winter in Beijing: Insights From High-Resolution Aerosol Mass Spectrometry, J. Geophys. Res.-Atmos., 124, 1132-1147, https://doi.org/10.1029/2018JD029245, 2019.

Yan, C., Zheng, M., Sullivan, A. P., Shen, G., Chen, Y., Wang, S., Zhao, B., Cai, S., Desyaterik, Y., Li, X., Zhou, T., Gustafsson, Ö., and Collett, J. L.: Residential Coal Combustion as a Source of Levoglucosan in China, Environ. Sci. Technol., 52, 1665-1674, https://doi.org/10.1021/acs.est.7b05858, 2018.

Ye, Z., Liu, J., Gu, A., Feng, F., Liu, Y., Bi, C., Xu, J., Li, L., Chen, H., Chen, Y., Dai, L., Zhou, Q., and Ge, X.: Chemical characterization of fine particulate matter in Changzhou, China, and source apportionment with offline aerosol mass spectrometry, Atmos. Chem. Phys., 17, 2573-2592, https://doi.org/10.5194/acp-172573-2017, 2017.

Zheng, Y., Cheng, X., Liao, K., Li, Y., Li, Y. J., Huang, R.-J., Hu, W., Liu, Y., Zhu, T., Chen, S., Zeng, L., Worsnop, D. R., and Chen, Q.: Characterization of anthropogenic organic aerosols by TOF-ACSM with the new capture vaporizer, Atmos. Meas. Tech., 13, 2457-2472, https://doi.org/10.5194/amt13-2457-2020, 2020.

Zhou, W., Jiang, J. K., Duan, L., and Hao, J. M.: Evolution of Submicrometer Organic Aerosols during a Complete Residential Coal Combustion Process, Environ. Sci. Technol., 50, 78617869, https://doi.org/10.1021/acs.est.6b00075, 2016. 